\title{
Experiencia de implementación del aprendizaje servicio en la Universidad Matej Bel en Banská Bystrica
}

\section{Zuzana Bariaková, Martina Kubealaková}

Matej Bel University in Banská Bystrica, Slovakia

\section{Resumen}

Se introduce la implementación del aprendizaje servicio en la educación en la Universidad Matej Bel en Banská Bystrica (Eslovaquia), centrado en la educación literaria. Se presenta un ejemplo de una actividad de aprendizaje servicio, el proyecto Noche de Literatura Universitaria. La experiencia realizada señala el desarrollo de una amplia gama de competencias (comunicativas, sociales, personales, de resolución de problemas, cívicas, culturales) a la par que el desarrollo de las competencias de aprendizaje sigue siendo el objetivo primordial. Las conclusiones ofrecen modificaciones del proyecto para su implementación en niveles educativos iniciales.

\section{Palabras clave}

Aprendizaje servicio, modelos de aprendizaje servicio en Eslovaquia, educación literaria, proyecto University Literature Night.

Fecha de recepción: 2/XII/2016

Fecha de aceptación: 1/III/2017 


\title{
Experience of Implementing Service Learning at Matej Bel University in Banská Bystrica
}

\begin{abstract}
The authors introduce implementation of service learning into education at MBU in Banská Bystrica (Slovakia) while putting particular emphasis on literary education. By concluding results of a research focused on the identification of student needs and by detailed introduction of the University Literature Night project, the authors present an example of an activity in which all standards and principles of service learning are included. The conclusion offers modifications of this project suitable for lower education. Emphasis has been placed on the development of a wide range of competences (communicative, social, personal, problem-solving, civic, cultural), but development of learning competencies remains the primary objective.
\end{abstract}

\section{Keywords}

Service learning, models of service learning in Slovakia, literary education, University Literature Night project. 
Service learning as a teaching and learning strategy intervening in multilateral as well as specific development of personality has a wide scale of use. Almost every U.S. university provides an educational programme based on principles of service learning, which results in defining service learning in various ways $^{1}$. The research team at Matej Bel University in Banská Bystrica defines service learning as an active teaching and learning strategy based on serving others while developing students' personality and forming their civic sense of responsibility. Simultaneously, it takes into account standards and principles of effective service learning which are included in The National Service-Learning Clearinghouse (NSLC).

In terms of defining the concept of service learning before its implementation into academic education at MBU in Banská Bystrica, Alžbeta Brozmanová Gregorová considered it important to clarify the position of service learning in relation to other forms of teaching, learning and students' participation. She emphasizes that while volunteering is more focused on service, professional practice focuses on education and development of specific competences required for the

\footnotetext{
${ }^{1}$ The use of the term service learning to denote a teaching strategy in the USA dates back to 1960s and it was gradually applied at all levels and types of schools. Consequently, it made it into educational systems of several European high schools and universities and spread into South America, Australia and Japan, too. Nowadays, this strategy is being used on two Slovak universities, University of Prešov in Prešov and at Matej Bel University in Banská Bystrica.
}

execution of the profession. Use of service learning helps to connect service and education. She sees the difference between service learning and professional practice as part of the preparation for the profession, above all in reciprocity (gains for both the student and the community/organisation) and focusing on developing the students' civic involvement (Brozmanová Gregorová 2013).

One of the pillars of service learning education is arousing students' will to learn whilst creating a sense of shared responsibility for this process. In other words, service learning disrupts the mistaken idea of one-way transfer of knowledge from teacher to student and his passive acceptance. In this manner, it places higher demands on all parties involved and gives the educational process a deeper meaning. Regardless of study programmes, service learning enables forming complex personalities. By no means does it replace the need for professional skills. However, by using specialized activities, it helps to link this need to the development of social-psychological personality. Simultaneously, the focus of service learning on practical experience underlines the theory, too.

The majority of schools in central Europe aim to adjust to a social trend according to which the quality of these schools depends directly on employability of their graduates in the labour market. We use this commercialized term on purpose, since many students approach their presence at schools under the pressure of 
consumer rules and the need of securing their fundamental existence. This approach is reflected, inter alia, in the emphasis on the inevitable link between school and practical life which -and very few of us realizes this- leads to deforming the meaning of education. Its main (and definitely not sole) objective should not only be preparation for successful managing of everyday life in the sense of developing a wide range of competences. However, if we understand this conception as a contemporary necessity, then it is a duty of educational institutions to search for opportunities of giving back to education its orientation on contextual (deeper) understanding and its persistence.

At this point, service learning appears to be a suitable strategy to achieve both goals. On the one hand, its pillars stand on cooperation between students, school and community, which supports linking education to practical experience and provides an opportunity to realise the realistic dimension of reached knowledge and personal development, its usability and limits. This way, service learning supports openness of the school environment to contemporary reality and by using specifically chosen activities, it supports preparation for successful integration as well as assertion. On the other hand, service learning can satisfyingly activate participating parties, among which students are the crucial ones. The phase of identifying their needs is, simply said, a phase of denomination of "what I don't know (well), but I want to know (better)". If this state is to be accomplished, we presume it will not only be a metaphor for arousing their will to know/understand, but that it will revive the once forgotten "partner in educational process", which is the sense of shared responsibility for education on the students' side. Our knowledge cannot only be a selective abstract of what others tell or show us.

If the strategy is to be understood this way, we conclude that implementation inevitably has to be anticipated by defining the needs of students, community and organization. Only then can we create/find an activity through which all detected needs can be fulfilled. It is also crucial to understand the fact that university forms not only future professionals specialized in various sections but also people who will understand their role in civic society and who actively participate on its development.

The Faculty of Education and the Faculty of Arts at MBU in Banská Bystrica, which implemented the service learning strategy into university education (more about models in Brozmanová Gregorová et al. 2014), prepare graduates in various study programmes, including pedagogy of academic subjects and social work. Research conducted to identify the expectations of implementing service learning into study programmes among respondents (316 respondents participated; more on research results e.g. in Bariaková and Kubealaková 2013) has shown that more than half of them expected the development of communication skills (active listening, presenting their opinion, leading a constructive dialogue), use of theory in 
practice, development of interpersonal relationships, development of project skills (improving skills concerning activity/event planning, implementation of this plan and evaluation, which includes experience with budget calculation) and development of organisation skills. One of the indispensable expectations was their interest in developing teamwork skills, which was supported by a team form of cooperation (preferred option), as well as in developing leadership and coordination skills. We consider these competences as crucial not only because they become an important part of professional life in different branches but also from an educational perspective, too. Art and culture, education and research were spheres of primary interest among students who wanted to work actively within the service learning framework. We presume this relates to the students' profile from these two faculties with pedagogic scope, which are strongly involved in research. However, even these have recently (over the past 10 years, approximately) been influenced by a trend to offer non-pedagogical study programmes.

Since the start of service learning implementation at MBU, our aim was to corroborate its separate phases empirically. Therefore, we performed a pre and post-test focused on detecting subjectively apprehended levels of competences among students who enrolled on Service Learning 1 and 2 and passed it. For testing, we used entrance and exit survey of competences (Brozmanová Gregorová et al. 2014) which focuses on the areas of communication competences, information competences, problem solving competences, teaching competences, social and personal competences, working and entrepreneurial competences, civic and cultural competences. In the pre-test, students had to pick ten skills they wanted to develop during their own service learning activity and in the posttest they picked 10 skills which they considered the most developed by service learning.

We can conclude that the subjectively apprehended level of chosen competences had increased among the students who passed service learning. This analysis confirms that service learning as a teaching strategy connecting theoretical education with practical experience helps students to develop skills directly related to their service learning activity, e.g. ability to work in difficult conditions and under pressure, ability to take responsibility for given tasks, ability to manage themselves on their own, ability to decide, set their personal aims, cooperate with professionals, as well as time management skills, ability to follow plans or create projects (plan an activity/event, implement this plan and evaluate it, calculate budget). Also interesting is the fact that students had rated the level of some of their skills as decreased -this includes ability to express their opinion, ability to learn and use new information as well as selfesteem and self-confidence-. This fact may relate to overestimation of their previous experience, knowledge, abilities and skills. 
However, facing a real service learning activity had moved them towards more precise self-evaluation. Even this can be considered a positive contribution of service learning to university education. We can also explain the finding that subjective evaluation did not rate learning competences positively by the fact that informal education is still not considered equal to formal education neither by students nor by a part of the academic community (more on results in the study by Heinzová et al.)-. We consider it important to state that the service learning team at MBU has evaluated these results in connection with the methodology of service learning education. Statistical verification of changes in subjective apprehension of students' competences after the second year has shown "a positive increase in average values of subjective level of communication competency in all cases" (Heinzová and Brozmanová Gregorová 2015).

Matej Bel University applies four models of service learning defined by Barbara Jacoby (1996): a course in which service learning represents an option (in the subject The Third Sector and Non-governmental Organizations); service learning as an alternative to a classical course (in the subject Work with Gypsy Community); a research conducted in a community (in the subject Methodology of Humanistic Science); a course of service learning (in the subject Service Learning 1 and 2). Taking into account the student needs identified, the principle of service learning and educational intentions of pedagogues, Service Learning 1 has been structured as a block of classes using unusual forms of education and Service Learning 2 represents its practical application. Separate blocks are interlinked and follow the internal structure of service learning steps. In the first block, terms of service learning, team dynamics and team formation are introduced to students. By the use of activating methods and tests, students identify their team role, they form teams according to their subjective preferences and analyse and reflect on its structure. They are introduced to the methodology of mapping and analysing needs.

Afterwards, their task is to identify community needs, define their default situation as well as their own situation.

In the second block they reflect on analysed needs collectively, which results in the definition of default situation of the service learning activity. Consequently, the aims of the service and aims of education are delineated and basic principles of planning are highlighted. The result of this block is a task focused on forming a plan of service learning activity which is afterwards discussed in a group debate. Particular attention is given to the theory of promotion and budget calculation, including applied output. In the end, the theory of evaluation and rules for project presentation are discussed. In the period of one semester students practise all phases of service learning education theoretically, as well as practically, and afterwards, in the second semester, they add details to particular phases and transform them into real service learning activities. During the evaluation and celebration phase when the activity is 
completed, students present and rate its benefits for the community and for themselves in the sense of level of fulfilment of their expectations and strengthening of the competences chosen at the beginning of the course.

The authors of this report focused particularly on the implementation of this issue into the subject Slovak Language and Literature, especially into its literary part. We took into account the specific profiles of graduates from study programmes involving Slovak language and literature (flexible, lingual and communicatively competent person invested in literary science; aesthetically-feeling specialist able to assert him/herself in a wide socialcultural sphere as an expert on teaching, cultivation and research of Slovak language and literature and on Slovak as a foreign language; an employee in the cultural sphere, an expert in tourism, presentation and preservation of (mainly written/printed) cultural artefacts; an expert in artistic production and its management, etc.) and on results of the research which has already been conducted. The authors afterwards carried out a research focused on students of Slovak Language and Literature in different study programmes (pedagogy, single and inter-programme study in combination with translation and interpreting). However, even this reduced form set by specification of the survey sample replicated and, therefore, confirmed results of previous research. These results repeatedly show that what students lack (prefer and ask for) the most is the cross connection of theory and their future practice (67\%) (Bariaková and Kubealaková 2015) ${ }^{2}$. A rather high percentage $(67 \%)$ of answers related to the issue of strengthening skills to choose suitable texts (both artistic and non-artistic) which would not only be attractive for pupils but for extramural audiences, too. These results not only impressed us, but they also inspired us to search for activities which would respond to almost all the needs revealed.

According to the research, students see potential in working with artistic and non-artistic texts not only in school environments and with traditional methods and forms but also outside of them. Their professional interest links here to their civic activism in the sense of spreading culture into their immediate environment, into which they want to involve their future pupils later on.

Some regions provide sufficient cultural stimulation, others fall short; yet book presentations and readings are a lowpriority subject of interest. Promotion of events involving the presentation of books is still lacking in Slovakia. Therefore, while competing for public attention, author readings and writerreader meetings fall short of festivals,

\footnotetext{
${ }^{2}$ Here you can find more on results of the research focused on students of study programmes in combination with Slovak language and literature (What type of cultural events connected with your future profession is most absent in your region? What type of an event in accordance to your answer in Question 1 would you be able to organise together with students of Slovak language and literature? Which skill connected with your suggested activities would you like to strengthen or gain?).
} 
concerts and theatre plays.

European Literature Night, which takes place in different European cities at the same time, represents an excellent opportunity to strengthen the skill of choosing suitable texts (artistic and non-artistic) which would be attractive to pupils as well as extramural audiences and to fulfil the demand for cultural events in the literary field. This event aims to introduce readers to works of European authors in untypical places which are usually not connected with literature.

This project, as we have realised, is very inspirational for us and we can modify it into smaller size and coverage (e.g. for needs of school, town). On this basis and in relation to recognising the needs of our students and the community (as well as of the school), the service learning activity called University Literature Night (henceforth, ULN) was developed. This resulted from the perception of (artistic) literature as a unique creative medium which reacts to the individual as well as to values of society in which he or she lives. The aim of this cultural event is to introduce contemporary Slovak and/or world literature to a wider audience while using an innovative method -a series of public readings and side events-.

The organising committee consists of a group of students who cooperate with three tutors from the pedagogical suite, but with the understanding that the organising responsibility lies with the students. Under the pressure of diverging ideas in the preliminary phases of activity planning, students have realised the practical dimension of theoretical information about teamwork and team role functions. As observing tutors, we consider this a key moment for all successive activities of the eventorganising group.

Organising ULN provides students with an opportunity to transfer their knowledge and previous experience to a new practical situation. They are forced to respond to all phases flexibly planning, planning in time, organising, implementation and evaluation of an event-. During group meetings they discover advantages and disadvantages of teamwork, they are led to consecutive reflection of their own participation, as well as of group participation, in a given phase of activity, they improve their communication skills not only within the group and team roles, but in relation to community and organization, too. They attend a series of meetings which aim to gain permission to organise this type of event and to find partners and sponsors.

This way, students are forced to prepare rigorously at the level of communication, argumentation and promotion and they get to learn about the legislative and functional background of the university and the city, too. They search for effective forms of promotion, consider its timing, coordinate PR happenings, they understand the need for strategy when choosing venues for readings, as well as when communicating with personalities who would likely agree to read, etc. Being involved in organising a ULN provides students with an outlet to 
fulfil needs which surfaced in both researches -development of communication skills (ability to empathise, active listening, presenting opinion, leading a constructive dialogue...); use of theory in practice; development of project skills (improving skills concerning activity/event plan, its implementation and evaluation, budget calculation); development of organisation skills just as well as relaxing, reducing stress and having fun-.

When considering possible types of service learning activity, the team intended to interlink special knowledge acquired during the study of several different programmes (pedagogy of Slovak language and literature in combination, translation and interpreting, European cultural studies, social work, pedagogy of psychology and pedagogics), and thus learn from each other, develop new competences and gain new experience. Students themselves felt the lack of cultural events organised for a wider public directly and realised the need to commit themselves more to the cultural life at the university and in the city. Above all, they were willing to experience organising an event involving a higher number of people (approximately 600 people attended both years of the event). In the end, they decided to organise a series of public readings of contemporary literature which took place in the university campus. This way, they responded to the need of the university to promote and present its activity as well as activity of its students for the general public. In relation to the community, students focused on targeting children -unusual readings in unusual places were to arouse their interest in books; then on targeting the Deaf community- who had previously pointed out the lack of cultural events that took into account their disability, thus resulting in interpreting all the readings into Slovak sign language; and, finally, targeting the wider public which was offered an opportunity to spend their leisure time meaningfully and to get to learn more about contemporary literature.

Since ULN is organised as a series of readings, students participate on the choice of texts, too. In the first phase, the selection criteria were specified: 1 . Contemporary works of Slovak or foreign authors that resonate in society; 2. Pursuit of analogy/link between the text, the reading venue and the reader; 3 . Purpose of reading/listening. Afterwards, the list of suggested works was finalised and in the last phase, the specific excerpts from the text chosen for public reading were identified (taking into account the aims of target group and of the event).

ULN has thus become an example of an activity that responds to the lack of visible involvement of educational institutions, as well as of students, in the cultural life of Banská Bystrica. By spreading culture and art in the area of the biggest educational institution ${ }^{3}$ in

\footnotetext{
${ }^{3}$ Matej Bel University in Banská Bystrica consists of 6 faculties and more than 20 pedagogical, scientific and other sites. In 2015, more than 10000 students in all degrees and forms of study, including more than 300 foreign students from 30 countries of the world, were studying at
} 
this city, ULN contributes to the preservation of cultural values, the enhancement of positive relationship of the public towards art, authors' work and reading in particular. The fact that this project is subsumed into a university-wide optional subject and is fully planned, organised, realized and evaluated by students under the professional lead of tutors confirms that student participation can represent an example of strengthening their civic responsibility, motivation to initiative an activity and rejection of passive acceptance of education, culture and service.

Art and literature are perceived as a means to eliminate (not only) communication barriers. Attendance of a wider public to this event can lead society to non-biased mutual reception and understanding. These aims, too, are considered obvious and the ULN organising team plans to participate on supporting the smaller and weaker and talented again this year.

In the first year, in 2014, contact with the Deaf community was established. In the same year, students worked with Koloman Kertész Bagala publishing house $^{4}$. This is a small firm, but it is

\footnotetext{
the university.

${ }^{4}$ Koloman Kertész Bagala publishing house was established in 1991 and it has introduced more than 400 books of Slovak writers to the Slovak book market. Thanks to his literary competition, Short Story, which it has been organizing since 1996, the publishing house has discovered many talented writers who were later awarded many other literary prizes. It actively promotes original Slovak works at home, as well as abroad; its events (chamber readings) Čau o piatej (Tea you at five) are very interesting.
}

conceptually important, since it focuses on publishing original works of Slovak prose. In 2015, students asked another smaller publishing house, Premedia, for co-operation. The choice of foreign literature represented the will to make the work of translators into Slovak more visible, just as well as the will to present interesting texts originating outside of Slovakia to the public. Cooperation with the civic association PONS -Pomoc osobám neschopným samostatnosti (Assistance to people incapable of self-reliance)- has also been established. This organization strives to create better life conditions for and educate children and youth with multiple disabilities; it helps them to integrate into society and creates conditions for their self-realization, even after the end of the educational process. One of the standpoints was dedicated to reading a fragment of a hitherto unpublished book by Simona Strelcová, a young talented author and a member of PONS association who, due to her illness, is unable to walk or speak. The ULN organising team developed a series of activities which eventually led to this book's publication.

The public was captivated by the idea of connection, education, cultural and humane development, lead towards tolerance, responsibility and non-biased involvement and the ULN project was voted the Volunteer Project 2014 in the Banská Bystrica region in December 2014. It was awarded the Srdce na dlani prize.

We believe that the ULN model we have presented may prove inspirational, as it can be adapted and conducted in 
various situations, considering actual needs and aims. Basic options for executing an activity at school could be: 1. An event organized by teachers for students and parents where students would be the target group, the so called listeners of the reading; 2 . An event organized by teachers in co-operation with a small group of students aimed at students and parents; 3 . An option similar to Option 2, however, in this case students would read the fragments, too.

We are convinced that the service learning strategy is able to fulfil many student demands, which reflected in reception after passing the service learning subject on at MBU in Banská Bystrica.

\section{References}

Bariaková Z, Kubealaková M. (2015). Umelecká literatúra medzi ludí prostredníctvom service learning. Edukácia. Vedecko-odborný časopis. 1(1), 12-19.

Bariaková Z, Kubealaková M. (2013). Tvorivá aplikácia vedomostí a zručností zo slovenského jazyka a literatúry $v$ stratégii service learning. Prešov: Prešovská univerzita v Prešove.

Brozmanová Gregorová A, et al. (2014). Service learning. Inovatívna stratégia učenia. Banská Bystrica: Belianum.

Brozmanová Gregorová A. (2013). Možnosti využitia service-learning $v$ pregraduálnej príprave sociálnych pracovníkov a pracovníčok.
Pregraduálna príprava sociálnych pracovníkov, pracovníčok a sociológov, sociologičiek a možnosti ich uplatnenia v praxi : zborník príspevkov z vedeckého seminára konaného dña 7 . decembra 2012 v Prešove. Prešov: Prešovská univerzita v Prešove.

Heinzová Z, Bariaková Z, Kubealaková M. (in print). Analýza rozvoja subjektívne vnímanej úrovne kompetencií študentov a študentiek prostredníctvom predmetu service learning na Univerzite Mateja Bela v Banskej Bystrici.

Heinzová Z, Brozmanová Gregorová A. (2015). Rozvoj komunikačných a sociálnych kompetencii študentov a študentiek UMB prostredníctvom predmetu service learning. Czlowiek w wielomiarowym obszarze dzialaň spolecznych. Kreacja, pomoc, interwencja, 26-46. 